\title{
Governing education policy: the European Union and Australia ${ }^{1}$
}

\author{
GOSIA KLATT \\ University of Melbourne \\ klattm@unimelb.edu.au
}

\author{
MARCELLA MILANA \\ University of Verona \\ marcella.milana@univr.it
}

\begin{abstract}
:
This paper considers the changing modes of governance of education policy in the European Union (EU) and Australia through a lens of 'soft governance'. It considers the increased use of 'policy instruments'such as benchmarking, targets, monitoring, data-generation in policy-making in recent decades. It considers the roles these policy instruments play in coordinating education policy in the $E U$ and Australia as well as their intended and unintended consequences. It shows that in the EU, these instruments played a role in strengthening the coordination through the links between individuals and programs, and networking, which is seen as resulting in enhanced creativity in policy solutions, development of new norms and new means for achieving policy goals. While in Australia it seems that the role of these instruments is focused on consolidating the role of the Commonwealth's oversight and control over what constitutionally is a responsibility of States which adds to several policy tensions already existing in the federal coordination of education.
\end{abstract}

Keywords: education policy, policy instruments, soft governance, benchmarks, target-setting, COAG

\section{Introduction}

Increasing education qualifications and upskilling have been on top of the agenda of national governments and international organisations in recent decades as a response to global economic pressures. The international response to these pressures has been the growth of an integrated approach to education and training through complex intersectoral policies including integrated lifelong learning (LLL) strategies, with LLL becoming an essential element of operating social and economic policies. International organisations such as OECD and UNESCO have been driving education policy trends focusing on developing the strategies of governing complex education systems to meet the demands of increasingly networked, multi-level and complex

\footnotetext{
${ }^{1}$ Acknowledgment - This paper draws on work undertaken under the project Encouraging Lifelong Learning for an Inclusive and Vibrant Europe (ENLIVEN). This project has received funding from the European Union's Horizon 2020 research and innovation programme under grant agreement No. 693989. It also incorporated some of the interviews conducted under the Australian Research Council's Linkage Project funding scheme (LP100100503). This article was also supported by the MGSE research development grant and I wish to express my appreciation for research support from Dr Elizabeth Hartnell-Young.
} 
systems (OECD 2016). At the same time, the European Union (EU) has developed a number of complex education policies coordinated through so called "soft policy instruments". Its policies encompass all levels and types of education but also include a focus on enhancing productivity, social cohesion, preventing radicalisation, and adjusting to the digital era. The effective coordination of European policy has been possible even though education policy has traditionally been a sovereign responsibility of each EU member state, and no transfer of power over education to European level has taken place. Nevertheless, the European education space or European Education Policy exists due to the continuous process of transforming governance processes at the European level (Nóvoa \& Lawn, 2002; Lawn, 2011). The EU's overarching objective is "to build a European Education Area to strengthen educational outcomes and learning mobility, promote common values and facilitate the mutual recognition of diplomas across borders" (European Commission n.d.). This is in the context of high levels of youth unemployment, low levels of literacy and numeracy among adults, growing social exclusion and radicalism.

Australia on the other hand has enjoyed relatively high post-compulsory education participation rates, steady economic growth and low unemployment rates and its approach to education policy has been characterised by its sectoral approach and the vertical division of power between Commonwealth and the States and Territories (Savage, 2017). However there are growing concerns that such an approach is not sustainable as wealth inequality and disadvantage continue to persist, especially in specific low SES areas. It is also clear that the structures of the Australian governance system, with its complex federal arrangements, and a variety of responsibilities for education shared between different levels of government has undermined a common vision and implementation of education policies for youth and adults. The calls for an integrated vision, in post-compulsory vocational and tertiary education, in particular, have been increasing as the post school education, training and employment rates have been deteriorating (Productivity Commission 2018). A recent study by the Mitchell Institute predicted a steep decline in tertiary education (VET and university) with participation dropping by $20 \%$ in the next two decades if the current policy approach to education continued (Dawkins, Hurley and Noonan, 2019). Dawkins et al. (2019) argued that federal and state governments need to come together to design fairer models for VET and Higher Education, especially in providing new funding models for VET studies. Furthermore, there is a growing need for inter-sectoral policy coordination that includes education, vocational training, industry skills, employment and it seems that the current VET system is not ready to respond to such expectations in a fair and innovative way. So far, the coordination of education policy objectives, design and implementation has been challenging in the Australian federal system where the responsibilities for different sectors of education require intergovernmental flexibility and collaboration.

Nevertheless, increasingly public policy has offered a variety of policy instruments available to policy-makers to better coordinate their efforts in a collaborative and networked way. In the EU, as well as in Australia, 'soft governance' policy instruments have been utilised to improve policy coordination and 'overcome' the limitations of traditional forms of regulation. As there are a number of concepts used in social sciences related to policy coordination, governance mechanisms and instruments, we will define our use of these concepts. Policy coordination is understood here in a very broad sense as a way of cooperating to avoid conflicts and to find policy solutions by utilising variety of tools such as communication or consultation (Peters 2018). 
Governance is a form of coordination of social actions with "formal and informal types of public interactions" (Pierre \& Peters 2000, p. 3). "Soft governance", in contrast to "hard governance" is an approach to policy-making (including policy design and implementation) that relies on voluntary forms of action (Bieber 2016). Soft governance is supported by a variety of governance mechanisms and "soft" policy instruments as will be discussed below.

Building on the "instrumentation" approach to understanding policy governance and policy coordination in complex multi-governance systems, the article will identify governance practices in support of common policy design and adoption practices utilised by the EU institutions. Such an approach will be useful in building our understanding of the ways through which education governance is operationalised, how governments operate and to observe the changing modes of governance in the EU and Australia (Le Galès 2011). On the example of the concept of policy instruments (i.e. coordinated networks, peer learning, data generation) used extensively by the EU institutions to promote specific discourses and objectives for education and training, it will discuss the use of similar policy instruments in the Australian context and their role in shaping the mode of governance of education space specifically the role of the policies at the Commonwealth level.

\section{'Instrumentation' approach to understanding education governance}

The formulation and implementation of public policy, including education, is no longer a domain of one public institution but increasingly depends on plural and networked forms of governance. Governance has a deep-seated collaborative nature (Salamon 2001) and relates to some kind of coordination of mutual interdependencies among variety of actors and their collective, 'new arenas' of power (Martens, Rusconi, \& Leuze, 2007). An effective coordination of complex governing has been seen as the "philosopher's stone" of public administration problems (Peters, 2018, p. 2). With growing globalisation pressures and an increasing number of intersectoral intergovernmental policies, there is a need for strategic coordination grounded in broad strategic goals of government which are linked to specific policy instruments (Peters, 2018). The spread of 'soft' governance through the implementation of the Open Method of Coordination (OMC) in the EU has therefore attracted an enormous body of research. One of the prominent contributions in the governmentality research has been inspired by Foucault, and developed by political sociologists Lascoumes and Le Galès (2007). This approach links the tradition in public policy studies with 'sociological analysis of forms of rationalization of power' (Le Galès 2011, p. 7) to address the relationships between government and the governed (see also Le Galès, 2016). Such an approach enables researchers to analyse a range of policy instruments and their effects on coordination of complex policies formulated and implemented in multi-level systems. Furthermore, Le Galès (2011, p.2) identified that the use of specific policy instruments may help us identify the changing modes of governance including a left democratic version promoting negotiation, and a right mode of governance using "technical instruments to centralize and promote a more marketoriented society".

In the context of the complex policy-making environment in the EU, drawing on the existing literature (e.g. Ravinet 2008, Williamson 2016), as well through the study of over 190 policy documents, we identified several governance mechanisms and policy 
instruments that are present in education governance (Milana \& Klatt 2019a, Milana, Klatt \& Vatrella 2020). By identifying the mechanisms and instruments, we were able to clarify how European governance (particularly policy coordination) facilitated domestic adaptation of Europe's lifelong learning markets and arguably influenced the competences and sovereignty of member states in dealing with social issues (cf. Milana \& Klatt 2019a, Milana, Klatt \& Vatrella 2020). Policy instruments that will be relevant to the below analysis include: coordinated working groups/networks, mutual- and peer-learning arrangements, data generation, benchmarks and indicators.

\section{Table 1 - Policy instruments used to implement European education policies}

\begin{tabular}{ll}
\hline $\begin{array}{l}\text { Policy } \\
\text { instrument }\end{array}$ & Description \\
\hline $\begin{array}{l}\text { Coordinated } \\
\text { working } \\
\text { groups/networks }\end{array}$ & $\begin{array}{l}\text { Groups established and coordinated by the European Commission } \\
\text { (EC), whose members, appointed by MSs' governments or the EC, } \\
\text { represent different positions (i.e. governmental agencies, other } \\
\text { stakeholders, experts), and are assembled, over a period of time, to } \\
\text { work on important policy issues in the area of education and } \\
\text { training. }\end{array}$
\end{tabular}

Mutual- and Occasions for representatives of MSs, and EC's staff that support peer-learning this activity, to identify and learn about initiatives and practices in arrangements place in different MSs (and beyond) in the area of adult learning.

Data generation The gathering of quantitative and/or qualitative data, the method used to generate data from different sources, and the procedure through which data reaches a database or otherwise organised collection of data.

Benchmarks Accepted standards at European level, at times negotiated and agreed among Heads of states and governments, by which MSs' performance in the area of education and training can be measured, compared, and thus their level of progress judged.

\begin{tabular}{ll}
\hline Funding & Plans or arrangements designed by EU institutions to encourage \\
schemes & governments, organizations or people to attain a particular \\
& objective or to put an idea into effect by providing money to finance \\
& an activity, a program, or a project entirely or in part.
\end{tabular}

Source: Milana \& Klatt (2019a)

These policy instruments have become an important coordination part in a number of educational policies in the EU including Education and Training framework (ET 2020), Renewed Agenda for Adult Learning, or European Youth Strategy (Milana, Klatt \& Vatrella 2020). Importantly, these policy instruments are linked to specific intended and unintended policy effects such as enforcing standards, encouraging conformity or operationalising specific norms and values, (Martens \& Jakobi 2010, Woodward 2010, Milana, Tronca \& Klatt 2019). Ravinet (2008), for instance, illustrates the process of instrumentation in European higher education by analysing how policy instruments used in the Bologna process (adaptation of higher education systems), have turned the originally flexible and informal policy process into an obligatory process at the European intergovernmental level. Ravinet argues that 
instruments used (scorecards, standardised reporting requirements and comparative tools) created 'a sense of obligation' and pressure on meeting the Bologna objectives. Similarly, Williamson (2016) argues that emerging public policy instruments have enabled new practices in data use and data analysis. Williamson's study maps how certain digital policy instruments function, and what social contexts frame them. His analysis of data visualisation tools is particularly illuminating as it demonstrates how technological advancements 'flatten and compress extraordinary complexity' of reality (ibid, p. 134). In brief, the study shows a change in style of education governance, where policy instruments (e.g. international assessments, quality criteria and comparative benchmarks) play a major role in shaping and framing education policy.

Therefore, the insight into the process of governing through a study of policy instruments may reveal how the objectives are instrumentalised and with what effects. In the EU, the development of European Education and Training strategic frameworks will provide an interesting example of policy instruments and their use.

\section{Education and Training Strategic Framework 2020 - European approach}

Although education has been a sovereign responsibility of national governments the EU institutions have increasingly extended their influence over social policies. This is similar to the Australian Commonwealth's incursions into governing education, however in the case of the EU, the European Council (all Heads of State) agree on specific policy objectives but then the policy approach and implementation, including specific policy instruments, are developed by the European Commission (European bureaucrats) in consultation with the European Parliament and civil society. These centralising trends have been driven, among other things, by the growing importance of investment in education for economic growth and through distribution of 'central' budget funding to the lower levels of policy-making.

In the last two decades, the EU has continuously provided leadership in education policy through development and implementation of a series of complex policy frameworks that provided roadmaps for reaching set policy objectives. Already in the year 2000, while the interest in integrated lifelong learning in Australia was declining, the EU member states agreed to implement a work program called Education \& Training 2010 (ET 2010). It was followed by the European Youth Strategy implemented in 2002, redeveloped in 2009 and 2018, as well as Renewed Agenda on Adult Learning agreed on in 2011.

The first framework for cooperation in education and training was significant as it outlined the first set of instruments supporting cooperation. These included: indicators and benchmarking, exchange of best practices, peer review, periodic monitoring and evaluation of the progress towards the objectives. These instruments of cooperation put in motion several 'governance mechanisms' such as standard setting, capacity building and elite learning (Héritier 2002, Martens \& Jakobi 2010, Milana, Klatt \& Vatrella 2020). ET 2010 provided a detailed roadmap for the member states in terms of objectives, methods and instruments to be used to achieve progress. For example, the mechanism of 'standard setting' was supported by 'benchmarking' and 'accountability' to meet these targets. These were reinforced by the publication of performance reports for each country and monitoring of their progress. The policy defined codes of best practice by setting out peer review processes and encouraging 
exchange of best practice. These processes are important in social ising and exchange of beliefs and value systems. The effects of these processes included support for the implementation of common European objectives in individual member states and led to a strengthened European integration process (Milana, Klatt \& Vatrella 2020).

The ET 2010 was updated in 2008 with an integrated framework for European cooperation in education and training - Education \& Training 2020 (ET 2020), which included four specific objectives, five benchmarks and a list of working methods. The progress on these objectives is supported by periodic monitoring. ET 2020 is seen as an 'integrated' framework as it refers to all levels and contexts of education. It serves as a policy umbrella for several parallel processes including Bologna, the Copenhagen process (conversion of vocational and training systems) and the development of a European qualifications framework. Lifelong learning is seen as an umbrella concept encompassing all other processes.

ET 2020 includes a number of measures to monitor implementation and the outcomes of the policy objectives. Benchmarking has been a popular policy instrument which is linked to 'data generation' and 'standard-setting' mechanisms (Milana \& Klatt 2019b). Since the Lisbon Council in 2000, indicators and benchmarks have been a cornerstone of European education and training policy, and are considered essential for its implementation (European Commission, 2004). In ET 2020 benchmarks are a part of the process established to achieve progress in European cooperation in education and training through open method of coordination and which includes, among others, common reference tools and approaches, peer learning and the exchange of good practice, including the dissemination of outcomes (Council of the EU, 2009, p. 119/4).

Furthermore, in ET 2020 the prominent data generation instrument is the Education and Training Monitor which was introduced in 2012, as a new annual Commission survey which outlined skills supply in the member states (European Commission, 2012). The Monitor includes quantitative comparative analyses, and country-specific recommendations based on Eurostat and OECD data, as well as studies done by the Eurydice network - the agency created by the European Commission to support information sharing about national education systems. Since 2013, these annually published monitors are accompanied by the individual Country Reports which identify where each country stands in relation to ET 2020 benchmarks and other indicators, as well as identifying challenges and strengths of each education system.

ET 2020 therefore consolidated the existing governance mechanisms such as standard setting (through benchmarks and indicators) and capacity building (strengthening 'good practice' exchange instruments). It significantly strengthened elite learning by expanding the peer review instrument through the addition of peer learning and peer counselling which are considered strong drivers for instigating change in the actors' beliefs and value systems.

Furthermore, the new generation of working groups which set common goals and policy objectives, coordinate activities and create stronger administrative ties with member state bureaucracies created an additional coordination space between the MSs and the EU. Coordinated working groups and mutual or peer-learning policy instruments play a significant coordinating function within ET and are examples of what Peters (2015) calls a collaboration approach to policy coordination. The coordination is strengthened through the links between individuals and programs, and 
networking, which is seen as resulting in enhanced creativity in policy solutions, development of new norms and new means for achieving policy goals. These are important networks which fit into the principles of soft governance with its stress on mutual learning, exchange of good practice and socialisation process, and which lies at the core of the Europeanisation of education (Lawn \& Grek, 2012). The connections made in these groups may possibly have a positive effect on domestic adoption of some rules developed in the network (Maggetti, 2014; Maggetti \& Gilardi, 2011).

It is important to emphasise that all these processes and instruments have a variety of policy consequences. The integrated intergovernmental policies, and the use of soft governance policy instruments, have created new opportunities in national education systems: from changes in administrative structures to setting policy agendas and policy implementation (Milana, Klatt \& Vatrella 2020). The peer learning activities, in-depth country workshops and other working group activities not only address specific thematic objectives, they also produce specific effects, independently of the objectives pursued. They bring together a variety of actors representing different interests and different beliefs and values, and create a space for socialisation and exchange of these values. At the same time, they initiate the development of national administrative adjustments, which influence the growing interdependence and future coordination of EU policies. Data generated by the work of the working groups includes recommendations, guidelines, background papers, flash reports and policy conclusions that are disseminated in each nation state. Data generation is among the instruments identified by the literature as a significant governance tool which influences the way education policy is made (Ozga, 2009; 2012; Lawn, 2013; Ravinet, 2008; Hodgson, 2011). There are number of 'tools' for producing information and evaluation, such as the Education and Training Monitor. These instruments influence 'the thinking and practices that shape and condition the policy' (Hodgson 2011, p. 116). In other words, these instruments 'carry values, worldviews, interpretations and political aspirations to coordinate and control education' (Lascoumes and le Galès, 2007, p. 125), which affect the social aspects of the relations shaped by these instruments. Big data is now embedded in education governance.

These are examples that represent the typical forms soft governance coordination. They are effective as they create opportunities to avoid duplication, contradiction, displacement and other undesirable effects of a lack of policy coordination (Peters 2018). Networks, collaboration, creating central coordinating structures and aligned procedures are all book-case examples of tools supporting policy coordination. Moreover, in case of the EU, it may be argued that its policy instruments illustrate more complex forms of policy coordination beyond the horizontal and vertical (Peters, 2018) with collaboration and networks being active across different governance levels, different policy sectors, and different nation states. The examples of policy instruments reflect different aspects of system transformations and modes of governance. Although the EU has created a strong emphasis on networked forms of governance such as expert groups and peer groups, its use of indicators, standards and purpose funding promotes a more market-oriented society. Furthermore, although the development and implementation of social policies at national levels have been 'notoriously resistant to the influence of Europeanization' (Héritier 2007, p. 10) it may be argued that the influence of these policy instruments and soft governance mechanisms penetrates the national structures, policy and practices leading to the permanent interdependence between the member states and the EU. 


\section{The Commonwealth approach to Education and Training in Australia}

It is important to note that at the time of development of the European ET 2020 framework, an important turn in the intergovernmental relations in Australia affected the way education policy has been made. In 2008, a reform of the fiscal arrangements between the Commonwealth and the States and Territories through the Intergovernmental Agreement (IGA) on Federal Financial Relations was agreed. The agreement was signed by the Prime Minister, Premiers and Chief Ministers at a meeting of the Council of Australian Governments (COAG), and took effect on 1 January 2009. It was described as "the single most significant shift in CommonwealthState relations for decades" as it established a new framework for collaboration in a variety of policy fields between the Commonwealth and State governments (COAG n.d.). In a nutshell, it changed the way Commonwealth funding was distributed to the States, removing a number of conditionalities and accountabilities in regard to special purpose payments. Kay (2015, p.414) argues that it marks "the critical juncture in an OMC trend within Australian federalism". Indeed, there are several 'soft governance' trends that may be observed following the reform with several soft policy instruments being included in the nationally-agreed policies; these include benchmarking, data generation, distribution of funding and sharing best practice however the latter has not been utilised on comparable scale with Europe.

In terms of similarities of policy instruments between the EU and Australia, the IGA introduced a set of performance measures such as indictors and benchmarks and assigned responsibility to the States/Territories for reporting against these. Furthermore, the Commonwealth provided financial incentives for implementing reforms and meeting certain policy outcomes through National Partnership payments. It is important to acknowledge that the National Partnership objectives were developed in close cooperation with and between the State representatives. As one of the New South Wales (NSW) senior bureaucrats admitted:

'we were very, very active in writing with the Commonwealth [on] the teacher quality national partnership. As in any arrangement there are elements that, if we were only writing it, we might not have put them in, but it's a negotiated environment' (Interview 1, Sydney, 2012).

There was a sense that globalisation and the national and international labour market required the Commonwealth and the States to create new arrangements where separate administrative and financial mechanisms in each State formed a partnership based on common standards for education and skills development (Interview 2, Sydney, 2012). However, the Commonwealth's approach to defining these objectives and targets transitioned from 'being fairly broad facilitation-based national partnerships (...) to now getting much, much more specific: so "we want to see certain forms of certain things happening in teacher quality"; "we want to see certain things happening in local empowerment of schools"..., and it's starting to get much more detailed' (Interview 1, Sydney, 2012).

Upon agreeing on specific objectives funded by National Partnership payments, all jurisdictions agreed to report on their progress in achieving benchmarks which was reported in a comparative perspective every year. A special role was played by the COAG Reform Council (CRC) which was independent from State governments and 
reported the comparative performance of jurisdictions (CRC was terminated in 2014). Additionally, each State reported individually on National Partnerships agreements to which reward funding contingent on the States and Territories achieving milestones or benchmarks were attached. The CRC was also tasked with highlighting good practices and sharing best practice examples with jurisdictions and the broader community (O'Loughlin, 2012). However, the reporting has been scaled back by new consecutive Commonwealth governments and since 2017-2018 is done through a Performance Reporting Dashboard managed by the Commonwealth Productivity Commission (2018).

Just like the coordination instruments in the EU, benchmarking and indicators play an increasingly important governance role and have been consolidated by the incoming governments. But unlike ET 2020, education and training have been viewed as separate sectors with separate objectives and benchmarks. The IGA was accompanied by two main National Agreements focused on education and training:

- National Agreement for Skills and Workforce Development (renewed in 2012)

- National Education Agreement (renewed as National Education Reform Agreement in 2014, and as National School Reform Agreement in 2019).

The National Agreement for Skills and Workforce Development aimed to 'work in partnership, and with businesses and industry, to develop the skills of the Australian people' (COAG 2008a, p.3) and included two targets:

- To halve the proportion of Australians nationally aged 20-64 without qualifications at Certificate III level and above between 2009 and 2020; and

- To double the number of higher level qualification completions (diploma and advanced diploma) nationally between 2009 and 2020 (COAG 2008a, p.6).

It also included an indicator that was looking at the proportion of VET graduates with improved employment status after training.

In the schooling sector, the National Education Agreement aimed at ensuring 'all Australian school students acquire the knowledge and skills to participate effectively in society and employment in a globalised economy' (COAG 2008b, p. 4). It had three targets:

- Lift the Year 12 or equivalent or Certificate II attainment rate to $90 \%$ by 2020

- Halve the gap for Indigenous students in reading, writing and numeracy within a decade;

- At least halve the gap for Indigenous students in Year 12 or equivalent attainment rates by 2020 (COAG 2008 b, p. 4).

The work on new intergovernmental arrangements was supported by a set of seven COAG working groups, chaired by a Commonwealth Minister (Carroll and Head 2010) and a Deputy Chair, typically a very senior state bureaucrat. For example, the working group responsible for education was chaired at the time by Julia Gillard who was the Commonwealth Minister and a Deputy Secretary in the NSW Department of Education (Interview 2, Sydney, 2012). Once the National Agreements were finalised, the new Ministerial Councils were set up to replace a large number of previous COAG Ministerial Councils that were, according to the former Premier of Victoria, perceived as barriers for reform "slowing things down and dampening reform" (Interview 3, 
Melbourne, 2011). The role of these new Ministerial Councils has created a space for soft governance arrangements, with one of the CRC members admitting "their effectiveness is highly dependent on their memberships (...) but it becomes more a workhouse for things, for the reforms, for the coming together, for the sharings' (Interview 1, Sydney, 2012). The sharing of ideas and collaborative work lies at the heart of peer group learning and creates a space for socialisation and exchange of these values so indeed the 2008 reform provided the potential for a more OMC type of governance.

Since 2008, the Commonwealth has seen a number of governments, and Prime Ministers, in power. The political volatility that the changing governments in Australia typically generate, including the new vision for federal arrangements by the Prime Minister Tony Abbott (Parliament of Australia 2014), abolishing of the CRC and restructuring COAG working groups have influenced the main policy instruments attached to the National Agreements as well. The abolishing of the CRC and focusing on targets and indicator monitoring through the Productivity Commission limits the policy instrumentation to one that aligns with a narrow neoliberal political rationality. For example, the first target set by the current National School Reform Agreement (2019-2023) is for 'Australia considered to be a high quality and high equity schooling system by international standards by 2025' (COAG 2018). The 'target' reflects rather a political vision than a measurable outcome with practical significance in the allocation of resources. Furthermore, progress on the school reform targets is enabled by supporting national policy initiatives focused specifically on assessment, monitoring, reviewing and strengthening the evidence-base by the States. One of the proposed initiatives included 'establishing an independent national evidence institute to inform teacher practice, system improvement and policy development' (COAG 2018, p. 9). The document's discourse represents a 'rationalist' model of public policy making which has been criticised for its reliance on the belief that significant social issues may be resolved by access to better information (Newman 2017) without a strategic plan of public mobilisation of activities to create an enabling environment for implementing change. Furthermore, the implementation of these national policy initiatives is a condition of Commonwealth funding to States and Territories. It seems that in the last decade Australian education policy has been limiting its governance to a narrow type of policy instruments which are mainly based on datafication of education: benchmarking, indicators, data generation. In tandem with the Commonwealth budgetary power, these have been used, to strengthen the Commonwealth's role in governing education.

\section{The Commonwealth mode of governance of Education and Training in Australia}

The analysis of the design and implementation of the policy instruments in the EU and Australia enables us to focus on the process of governing characterising these polities. Both European and Australian policy-makers set targets and benchmarks for education and training that included a set of incentives as well as monitoring devices. These characterise market-oriented modes of governance but each with its own challenges. Both struggled with achieving real progress in lifting education attainment, qualification levels and addressing inequality. Nevertheless, in the EU a variety of administrative, normative and policy transformations have taken place through the 'capacity-building' and 'elite learning' governance mechanisms. In Australia, despite the growing datafication of education, benchmarking and incentivising education 
initiatives, high numbers of Australians face significant challenges in upskilling, employment and democratic participation: over 20\% of young people do not complete Year 12 (ACARA 2017), while over 1 million adult Australians do not have basic literacy skills (ABS 2018). The education and upskilling targets from the 2008 Agreements have not been met in Australia (with the exception of targets set for access to quality early childhood education which received a substantial funding boost).

Apart from illuminating policy objectives, policy instruments have a role in coordinating design and implementation of the actions that support these objectives. In the EU, these instruments helped coordinating what the EU needed the most: a common vision for 28 members and harmonization of education policies and systems as a means for increasing students and worker mobility, employability and social cohesiveness. Furthermore, while some point out the democratic deficit and the growing governing by numbers, the EU's policies also provide roadmaps, processes and public mobilisation in member states creating conditions for change (e.g. Broek \& Buiskool, 2012). While in Australia, it seems that the role of these instruments is focused on consolidating the role of the Commonwealth's oversight and control over what constitutionally is a responsibility of the States. There are two important policy tensions here where the Commonwealth has increasingly influenced the policy space. The first is related to 'agenda-setting', the central role of COAG as a space for national goal-setting. Second is monitoring and conditionality of policy adoption in the States and Territories. The centralisation of education policy may lead to growing federalstate tensions over policy implementation. The process is driven by the attention to monitoring and compliance through the central role of COAG, Commonwealth Ministers and Senior officials (Carroll \& Head 2010). The instruments used in governing Australian education have hierarchical and formal characteristics with the Commonwealth in charge of the agenda and overall policy objectives continuing the trend of so-called 'cooperative federalism' which incrementally leads to centralisation (Fenna 2009, Kay 2015). Although COAG has been seen as an effective means of improving coordination and cooperation in policy making across portfolios nationally (Jones 2008; Keating \& Wanna 2000) it has also been criticised for lack of effectiveness and its reactive rather than proactive nature (Parliament of Australia, 2011, p.49).

In Australia the use of soft policy instruments by the Commonwealth government is limited to a specific governing purpose through two main governance mechanisms: 'standard-setting' through benchmarking and targets, and 'financial redistribution' through specific purpose payments (SPPs) and National Partnerships conditionality and reporting. But mechanistically determined 'standard setting' rather than inclusive process (characterised by collaboration, communication, feedback, sharing, and empowerment) leads to a lack of transparency and limited benefits (Martínez \& Dopheide 2014). In contrast, in the case of the EU it is the collaborative policy instruments that have proliferated in the governance space. These were not developed in Australia. The use of policy instruments seems to confirm that the Australian policy system has been 'incapacitated' by the preoccupation with the vertical division of power between Commonwealth and the States and Territories (Savage 2017). As Savage (2017) suggested, the re-focusing on networks of collaboration may provide a much needed flexibility in political imagination in education policy-making. The EU model of 'soft governance' instruments which are based on vertical and horizontal collaboration networks managed and coordinated by the supranational institutions may provide a good starting point for the Australian context. Obviously, soft 
governance instruments must be seen in conjunction with, and as a part of, a longterm policy coordination strategy of the Australian governments. But it seems that they offer an opportunity for the Commonwealth government, instead of focusing on control and accountability of the State actors, to play a stronger leadership role in driving collaboration through introducing new collaborative policy instruments.

\section{List of Interviews}

(Interview 1) A senior manager from the New South Wales Department of Education and Training (Sydney, 7 February 2012).

(Interview 2) A senior manager from the Council of Australian Governments Reform Council (Sydney, 7 February 2012).

(Interview 3) Former Premier of Victoria, Steve Bracks (Melbourne, 13 December 2011).

\section{References}

ACARA. (2017). Year 12 certification rates. https://www.acara.edu.au/reporting/national-report-on-schooling-in-australia-data-portal/year-12-certification-rates. Accessed 20 September 2019.

Australian Bureau of Statistics. (2018). Programme for the International Assessment of Adult Competencies, Australia, 2011-12.

http://www.abs.gov.au/ausstats/abs@.nsf/Lookup/4228.oMain+Features20201112. Accessed 20 September 2019.

Bieber, T. (2016). Soft governance, international organizations and education policy convergence: comparing PISA and the Bologna and Copenhagen processes. London: Palgrave Macmillan.

Broek, S., \& Buiskool, B.-J. (2012). Mapping and Comparing Mobilisation Strategies Throughout Europe: Towards Making Lifelong Learning a Reality. Journal of Adult and Continuing Education, 18(1), 4-26.

Carroll, P., \& Head, B. (2010). Regulatory Reform and the Management of Intergovernmental Relations in Australia. Australian Journal of Political Science, 45(3), 407-424.

Council of Australian Governments (COAG). (2008a). National Agreement for Skills and Workforce Development. Archived COAG webpage from 17 March 2012.

National Library of Australia

Council of Australian Governments (COAG). (2008b). National Agreement for Skills and Workforce Development. Archived COAG webpage from 17 March 2012. National Library of Australia (Trove online service).

Council of Australian Governments (COAG). (2018). National School Reform Agreement. http://www.federalfinancialrelations.gov.au/content/npa/national agreements/past/national-education-agreement.pdf. Accessed 10 May 2019 
Council of Australian Governments (COAG). (n.d.). Intergovernmental Agreement on Federal Financial Relations. Retrieved from https://www.coag.gov.au/content/intergovernmental-agreement-federal-financial-relations. Accessed 10 May 2019

Council of the European Union (2009). Council Conclusions of 12 May 2009 on a strategic framework for European cooperation in education and training ('ET 2020'). Brussels: The Council of the European Union. https://eur-lex.europa.eu/legalcontent/EN/ALL/?uri=CELEX:52009XG0528(01). Accessed 25 June 2019

Dawkins, P., Hurley, P., \& Noonan, P. (2019). Rethinking and revitalising tertiary education in Australia. Retrieved from Melbourne: http://www.mitchellinstitute.org.au/wp-content/uploads/2019/05/Rethinking-and-revitalising-tertiaryeducation-FINAL.pdf. Accessed 26 September 2019

European Commission (2004). Progress towards the common objectives in education and training. Indicators and benchmarks. SEC(2004) 73. Brussels: The European Commission

European Commission (2012). Education and Training Monitor 2012. Brussels: The European Commission.

European Commission (n.d.). Education and Training. European Education Area. https://ec.europa.eu/education/education-in-the-eu/european-education-area en. Accessed 10 May 2019.

Fenna, A. (2009). Federalism. In R. Rhodes (Ed.), The Australian Study of Politics (pp. 146-159). Basingstoke: Palgrave Macmillan.

Héritier, Adrienne (2002). New Modes of Governance in Europe: Policy Making without Legislating?. Political Science Series, 81, 1-33.

Héritier, A. (2007). Explaining Institutional Change in Europe. Oxford, UK: Oxford University Press.

Hodgson, D. (2011). Policy rationalities and policy technologies: a programme for analysing the raised school-leaving age in Western Australia. Journal of Education Policy, 26(1), 115-130.

Jones, T. (2013). Understanding education policy: the 'Four education orientations' framework. Dordrecht; New York: Springer.

Kay, A. (2015). Separating Sovereignty and Sharing Problems: Australian Federalism and the European Union. Australian Journal of Public Administration 74 (4), 406418.

Keating, M., \& Wanna, J. (2000). Remaking federalism? In M. Keating, J. Wanna, \& P. Weller (Eds.), Institutions on the edge? Capacity for governance. St Leonards, N.S.W.: Allen \& Unwin.

Lascoumes, P., \& Le Gales, P. (2007). Introduction: Understanding Public Policy through Its Instruments-From the Nature of Instruments to the Sociology of Public Policy Instrumentation. Governance, 2O(1), 1-21.

Lawn, M. (2013). A Systemless System: Designing the Disarticulation of English State Education. European Educational Research Journal, 12(2), 231-241.

Lawn, M., \& Grek, S. (2012). Europeanizing education: governing a new policy space. Oxford: Symposium Books. 
Le Gales, P. (2011). Chapter 10: Policy Instruments and Governance. In M. Bevir (Ed.), The SAGE Handbook of Governance (pp. 142-159). London: SAGE Publications.

Le Galès, P. (2016). Performance measurement as a policy instrument. Policy Studies, 37(6), 508-520.

Maggetti, M. (2014). The Politics of Network Governance in Europe: The Case of Energy Regulation. West European Politics, 37(3), 497-514.

Maggetti, M., \& Gilardi F. (2011). The Policy-making Structure of European Regulatory Networks and the Domestic Adoption of Standards, Journal of European Public Policy, 18(6), 830-47.

Martens, K., Rusconi, A., \& Leuze, K. (2007). New arenas of education governance: the impact of international organizations and markets on educational policy making. Basingstoke: Palgrave Macmillan.

Martens, K. \& Jakobi, A. (2010). Mechanisms of OECD governance: international incentives for national policy-making? Oxford: Oxford University Press.

Martínez, J., \& Dopheide, E. (2014). Indicators: from Counting to Communicating. Journal for Education in the Built Environment, 9(1), 1-19.

Milana, M., \& Klatt, G. (2019a). Governing Adult Education Policy Development in Europe: A critical appraisal of the Renewed Agenda for adult learning. In S. McGrath, M. Mulder, J. Papier, \& R. Suart (Eds.), Handbook of Vocational Education and Training: Developments in the Changing World of Work (pp. 1-25). Switzerland: Springer.

Milana, M., \& Klatt, G. (2019b). Introduction. In M. Milana, S. Vatrella, \& G. Klatt (Eds.), Report on the use of PIAAC in informing policy in selected countries. Brussels: European Commission.

Milana, M., Klatt, G., \& Vatrella, S. (Eds.). (2020). Europe’s Lifelong Learning Markets, Governance and Policy. Using an Instruments Approach. Cham, Switzerland: Palgrave Macmillan.

Milana, M., Tronca, L., \& Klatt, G. (2019). European Governance in Adult Education: On the comparative advantage of joining working groups and networks. The European Journal for Research on the Education and Learning of Adults.1-27. http://www.rela.ep.liu.se/issues/prepublished/844/rela_844.pdf Accessed 10 October 2019.

Newman, J. (2017). Deconstructing the debate over evidence-based policy. Critical Policy Studies, 11(2), 211-226.

Nóvoa, António \& Lawn, Martin (2002). Fabricating Europe: The Formation of an Education Space. Dordrecht: Springer Netherlands.

OECD. (2016). Governing Complex Education Systems (GCES). http://www.oecd.org/education/ceri/gces.htm.

O'Loughlin, M. A. (2012). Benchmarking and accountability: the role of the COAG Reform Council. In A. Fenna \& F. Knupling (Eds.), Benchmarking in Federal Systems, Roundtable Proceedings (pp. 247-265). Canberra: Productivity Commission. https://www.pc.gov.au/research/supporting/benchmarking-federalsystems/13-benchmarking-federal-systems-chapter11.pdf Accessed 10 May 2019 
Ozga, J. (2009). Governing education through data in England: from regulation to self-evaluation. Journal of Education Policy, 24(2), 149-162.

Ozga, Jenny (2012). Governing knowledge: data, inspection and education policy in Europe. Globalisation, Societies and Education, 10(4), 439-455.

Parliament of Australia. (2011).Australia's Federation: an agenda for reform. Select Committee on the Reform of the Australian Federation. https://www.aph.gov.au/Parliamentary Business/Committees/Senate/Former Committees/reffed/r effed/report/c03. Accessed 20 September 2019

Peters, B. (2015). Approaches to Understanding Coordination. In B. Peters (Ed.), Pursuing Horizontal Management (pp. 45-73). Lawrence, Kansas: University Press of Kansas.

Peters, B. (2018). The challenge of policy coordination. Policy Design and Practice, 1(1), 1-11.

Pierre, J., \& Peters, B. (2000). Governance, politics and the state. New York: St. Martin's Press.

Productivity Commission (2018). Performance reporting dashboard. https://performancedashboard.d61.io/aus. Accessed 10 September 2019

Ravinet, Pauline (2008). From Voluntary Participation to Monitored Coordination: Why European Countries Feel Increasingly Bound by Their Commitment to the Bologna Process. European Journal of Education, 43(3), 353-367.

Salamon, L. M., \& Elliott, O. V. (2001). The tools of government: a guide to the new governance: New York: Oxford University Press.

Savage, G. (2017). Improving national policy processes in Australian schooling. In T. Bentley \& G. Savage (Eds.), Educating Australia: challenges for the decade ahead (pp. 348-366). Melbourne: Melbourne University Publishing Ltd.

Williamson, B. (2016). Digital education governance: data visualization, predictive analytics, and 'real-time' policy instruments. Journal of Education Policy, 31(2), 123141.

Woodward, R. (2010). The OECD and Economic Governance: Invisibility and Impotence? In K. Martens \& A. P. Jakobi (Eds.), Mechanisms of OECD Governance: International Incentives for National Policy-Making? Oxford: Oxford Scholarship. 